\title{
PENGARUH KOMPENSASI TERHADAP KINERJA PERUSAHAAN PADA PT. BERLIAN JASA TERMINAL INDONESIA CABANG KUPANG
}

\author{
Teddy Yosias Sentinuwo ${ }^{1)}$ Gasim $^{2)}$ Akbar Yusuf ${ }^{2)}$ \\ ${ }^{1)}$ Alumni Program Studi Akuntansi Universitas Muhammadiyah Kupang \\ ${ }^{2)}$ Alumni Program Studi Akuntansi Universitas Muhammadiyah Kupang
}

\begin{abstract}
To improve performance, companies have to deal with several ways: by providing adequate compensation in accordance with the contribution of the company and a quality of life as well as a conducive work environment to create. This study aimed to determine the effect of the financial compensation and non-financial compensation performance of the company PT. Berlian Jasa Terminal Indonesia Branch Kupang, the influence of financial and non-financial compensation simultaneously on the performance of PT. Berlian Jasa Terminal Indonesia Branch Kupang. The sample is in this study was 64 respondents were distributed to employees of PT. Berlian Jasa Terminal Indonesia Branch Kupang. Data analysis method is used, the quantitative analysis and use of analytical tools SmartPLS3. The results of the study for financial compensation positive and significant impact on the performance of PT. Berlian Jasa Terminal Indonesia Branch Kupang, non-monetary compensation is also positive and significant impact on the performance of PT. Berlian Jasa Terminal Indonesia Branch Kupang, financial and nonfinancial compensation simultaneously positive and significant impact on the performance of PT. Berlian Jasa Terminal Indonesia Branch Kupang.
\end{abstract}

Keywords : Financial compensation, compensation of non-financial, corporate performance.

\section{PENDAHULUAN}

Dalam meningkatkan kinerja karyawan yang dilakukan adalah dengan menempuh beberapa cara misalnya melalui pendidikan, pelatihan, pemberian kompensasi yang layak, menciptakan lingkungan kerja yang kondusif dan pemberian motivasi. Melalui proses-proses tersebut, seorang karyawan diharapkan akan lebih memaksimalkan tanggung jawab atas pekerjaan mereka karena para karyawan telah terbekali oleh pendidikan dan pelatihan yang tentu berkaitan dengan implementasi kerja mereka. Kompensasi memegang peranan penting dalam meningkatkan kinerja pegawai, karena salah satu alasan utama seseorang bekerja adalah untuk memenuhi kebutuhan hidupnya. Pemberian kompensasi dimaksudkan agar pegawai dapat bekerja secara maksimal sehingga menghasilkan kinerja yang optimal. Panggabean (2004:76)

Penelitian tentang hubungan variabel-variabel kompensasi yang terdiri atas kompensasi finansial dan nonfinansial dengan kinerja/prestasi kerja karyawan telah banyak dilakukan sebelumnya. Menurut Allo (2002), Rahayu (2007) dan Polnaya 
(2007) pemberian kompensasi yang tepat merupakan salah satu cara yang dapat digunakan untuk meningkatkan motivasi bagi karyawan sehingga mencapai kinerja yang diinginkan perusahaan. Penelitian Polnaya (2007) mengenai pengaruh antara kompensasi finansial dan nonfinansial terhadap kinerja dosen, menyatakan bahwa ada pengaruh yang positif dan signifikan antar kompensasi finansial dan nonfinansial terhadap kinerja dosen. Penelitian yang dilakukan oleh Polnaya (2007) menggunakan populasi pada Universitas Kristen Indonesia Maluku dengan sampel dosen.

Berbeda dengan penelitian sebelumnya, penelitian ini mengambil populasi karyawan pada PT. Berlian Jasa Terminal Indonesia Cabang Kupang. Penelitian ini dilakukan dengan metode survei, yaitu mengambil data dengan memberikan kuesioner kepada karyawan PT. Berlian Jasa Terminal Indonesia Cabang Kupang sedangkan data sekunder sebagai pendukung.

Berdasarkan latar belakang di atas maka tujuan penelitian ini adalah 1) untuk membuktikan bahwa kompensasi Finansial berpengaruh terhadap kinerja perusahaan, 2) untuk membuktikan bahwa kompensasi Non-finansial berpengaruh terhadap kinerja perusahaan.

\section{TINJAUAN PUSTAKA}

\section{Kompensasi}

Menurut Handoko dalam Mulyadi (2012), kompensasi adalah segala sesuatu yang diterima para karyawan sebagai balas jasa untuk kerja mereka. Upah atau gaji pokok adalah pembayaran yang diterima karyawan secara bulanan, mingguan, atau setiap jam sebagai hasil dari pekerjaan mereka. Menurut J. Long (1998:8) dalam bukunya Compensation in Canada mendefinisikan sistem kompensasi adalah bagian (parsial) dari sistem reward yang hanya berkaitan dengan bagian ekonomi, namun demikian sejak adanya keyakinan bahwa perilaku individual dipengaruhi oleh sistem dalam spektrum yang lebih luas maka sistem kompensasi tidak dapat terpisah dari keseluruhan sistem reward yang disediakan oleh organisasi.

Ada beberapa definisi kompensasi yang dikemukakan oleh para ahli, diantaranya Sastrohadiwiryo (2005:181) mengemukakan bahwa : Kompensasi adalah imbalan jasa atau balas jasa yang diberikan oleh perusahaan kepada para tenaga kerja, 
karena tenaga kerja tersebut telah memberikan sumbangan tenaga dan pikiran demi kemajuan perusahaan guna mencapai tujuan yang telah ditetapkan.

Menurut Martoyo (2007:116) "kompensasi adalah pengaturan keseluruhan pemberian balas jasa bagi employers maupun employees baik yang langsung berupa uang (finansial) maupun yang tidak langsung berupa uang (nonfinansial)". Menurut Hasibuan (2008:118) "kompensasi adalah semua pendapatan yang berbentuk uang, barang lang sung atau tidak langsung yang diterima karyawan sebagai imbalan atas jasa yang diberikan kepada perusahaan".

Jadi kompensasi merupakan suatu pemberian berupa penghargaan dan juga suatu apresiasi kepada hasil kerja dari para karyawan, maka para manajer mempunyai standar yang berupa sistem kompensasi berpengaruh dalam kinerja, karena kinerja karyawan menyangkut dengan hasil akhir dari penilaian-yang menjadi pertimbangan bagi manajer perusahaan untuk mengevaluasi seluruh kegiatan dalam perusahaan dan juga manajer mempunyai wewenang untuk memberikan suatu kompensasi berupa : penghargaan (reward), naik jabatan, naik gaji dan lain-lain.

\section{Kinerja Perusahaan}

Kinerja perusahaan merupakan penentuan ukuran-ukuran tertentu yang dapat mengukur keberhasilan suatu perusahaan dalam menghasilkan laba (Sucipto, 2003). Menurut Febryani dan Zulfadin (2003) dalam Cornelius (2007) kinerja perusahaan merupakan hal penting yang harus dicapai oleh setiap perusahaan dimana pun, karena kinerja merupakan cerminan dari kemampuan perusahaan dalam mengelola dan mengalokasikan sumber dayanya. Kinerja perusahaan adalah kemampuan perusahaan dalam menjelaskan operasionalnya (Payatma, 2001).

\section{Hubungan antara Pemberian Kompensasi dengan Kinerja Perusahaan.}

Dengan kompensasi kepada pekerja diberikan penghargaan berdasarkan kinerja dan bukan berdasarkan senioritas atau jumlah jam kerja (Werther dan Davis dalam Mulyadi 2012). Menurut Simamora (2004) mengatakan bahwa kompensasi dalam bentuk finansial adalah penting bagi karyawan, sebab dengan kompensasi ini mereka dapat memenuhi kebutuhannya secara langsung, terutama kebutuhan fisiologisnya.

Dalam penelitian sebelumnya, Allo (2007) meneliti analisis kompensasi dan 
pengaruhnya terhadap kinerja petugas P3KB pada Dinas Kehutanan Propinsi Sulawesi Tengah. Hasil penelitian tersebut diperoleh kesimpulan bahwa kompensasi finansial langsung mempunyai hubungan korelasi positif tinggi yang paling dominan terhadap kinerja petugas P3KB pada Dinas Kehutanan Propinsi Sulawesi Tengah dibandingkan kompensasi finansial tidak langsung dan kompensasi nonfinansial.

Berdasarkan definisi dan penelitian terdahulu diatas maka hipotesis yang dirumskan dalam penelitian adalah:

$H_{1}$ : Pemberian Kompensasi Finansial berpengaruh positif dan signifikan terhadap kinerja perusahaan

$\mathrm{H}_{2}$ : Pemberian Kompensasi Non-Finansial berpengaruh positif dan signifikan terhadap kinerja perusahaan

\section{METODE PENELITIAN}

\section{Desain Penelitian}

Desain penelitian yang digunakan untuk menganalisis penelitian ini yaitu dengan pendekatan explanatory research, karena penelitian ini bermaksud untuk menjelaskan hubungan kausal antara variabel-variabel dengan melalui pengujian hipotesis yang telah dirumuskan. Kuesioner yang digunakan diadopsi oleh peneliti dari Apriyani (2010) yang berdasarkan pada teori terkait.

\section{Populasi dan Sampel}

Populasi dalam penelitian ini adalah Karyawan yang bekerja pada PT. Berlian Jasa Terminal Indonesia Cabang Kupang. Sampel penelitian ini diambil menggunakan teknik "purposive sampling" dengan kriteria yang ditentukan sendiri oleh peneliti yaitu setiap karyawan yang bertugas pada PT. Berlian Jasa Terminal Indonesia Cabang Kupang. Data diperoleh dengan membuat daftar pertanyaan (kuesioner) yang diadopsi dari Apriyani (2010), kemudian peneliti kembangkan lagi disesuaikan dengan situasi dan teori yang terkait. Penyebaran kuesioner dilakukan secara langsung (kuesioner diantarkan langsung ke responden yang bersangkutan) untuk setiap karyawan. Kuesioner disebarkan sebanyak jumlah Karyawan yang bekerja pada perusahaan tersebut. 


\section{Definisi Operasional dan Penguluran Variabel}

\section{Variabel Independen}

Variabel independen dalam penelitian ini adalah kompensasi, yaitu segala sesuatu yang diterima karyawan sebagai balas jasa untuk kerja mereka. Variabel dari kompensasi yaitu :

a) Kompensasi Finansial indikator yaitu :

1. Gaji

2. Bonus

3. Program-program proteksi dengan indikator yaitu asuransi tenaga kerja, asuransi kesehatan, tunjangan pensiun (pesangon).

b) Kompensasi Non-finansial indikator :

1. Pekerjaan, dengan indikator yaitu tugas-tugas yang menarik, tantangan- tantangan, tanggung jawab, pengakuan dan rasa pencapaian.

2. Lingkungan pekerjaan, dengan indikator kebijakan-kebijakan yang sehat, supervisi yang kompeten, kerabat kerja yang menyenangkan dan lingkungan kerja yang menyenangkan.

\section{Variabel dependen}

Variabel dependen dalam penelitian ini adalah kinerja perusahaan diukur menggunakan metode balanced scorecard (Kaplan dan Norton ,1992) menggunakan empat perspektif : keuangan, pelanggan, proses bisnis internal, pembelajaran dan pertumbuhan. Ringkasan penjabaran dari keempat perspektif itu adalah sebagai berikut:

1. Financial perspective, memberikan sasaran keuangan yang perlu dicapai oleh organisasi dalam mewujudkan visinya.

2. Customer perspective, memberikan gambaran segmen pasar yang dituju dan pelanggan beserta tuntutan kebutuhan yang dilayani oleh organisasi dalam upaya untuk mencapai sasaran keuangan tertentu.

3. Internal and Proses Business Perspective, memberikan gambaran proses yang harus dibangun untuk melayani pelanggan dan untuk mencapai sasaran keuangan tertentu.

4. Learning and Growth perspective, merupakan pemacu untuk membangun kompetensi personel, pra sarana system 


\section{Uji Hipotesis}

Di uji dengan model empiris:

YKinerja $=\beta 0^{+} \beta 1_{\mathbf{P K}}+\beta 2_{\mathbf{P K}}+\mathrm{e} \ldots$

Keterangan :

YKinerja $=$ Kinerja Perusahaan

$\beta 0=$ Konstanta

$\beta 1 \mathrm{PK} .=$ Pemberian Kompensasi Finansial

$32 \mathrm{PK} .=$ Pemberian Kompensasi Non-Finansial

$\mathrm{e} \quad=\quad$ Error

\section{HASIL PENELITIAN DAN PEMBAHASAN}

\section{Deskripsi Responden}

Penelitian ini mengangkat permasalahan mengenai pengaruh kompensasi finansial dan kompensasi non-finansial terhadap kinerja perusahaan pada PT. Berlian Jasa Terminal Indonesia Cabang Kupang. Rincian deskripsi penelitian dapat dilihat pada tabel berikut ini.

\begin{tabular}{|l|l|}
\hline Populasi & 64 Orang \\
\hline Jenis Kelamin Laki-laki & 63 orang. \\
\hline Jenis Kelamin Perempuan & 1 Orang \\
\hline Sample & 64 orang \\
\hline Kuesioner yang disebarkan & 64 Eksempelar \\
\hline Kuesioner yang kembali & 64 Eksampelar \\
\hline Kuesioner yang rusak & - \\
\hline Kuesioner yang dipakai untuk analisis & 64 Eksampelar \\
\hline
\end{tabular}

\section{Uji Validitas}

\begin{tabular}{|l|l|}
\hline & Original Sampel $(\mathrm{O})$ \\
\hline Kinerja Perusahaan (Y) & 0.513 \\
\hline Kompensasi Finansial (X1) & 0.578 \\
\hline Kompensasi Non-Finansial (X2) & 0.562 \\
\hline
\end{tabular}

Berdasarkan hasil uji Variabel Kompensasi Finansial (X1) terhadap 64 responden dengan 12 item pertanyaandengan rata-rata loading factor di atas standar 0.50 dinyatakan lolos untuk dilakukan uji selanjutnya. Dan untuk melihat validitas dari masing-masing konstruk dapat diuji dengan AVE (average variance extracted). 
Konstruk dengan validitas yang baik dipersyaratkan nilai AVE harus di atas 0,50, maka variabel Kompensasi Finansial (X1) dengan nilai AVE 0.56 dapat dikatakan memiliki nilai validitas yang baik.

Hasil Uji validitas Variabel Kompensasi non-Finansial (X2) sebagai variabel terhadap 64 responden dengan 12 item pertanyaan dengan rata-rata loading factor di atas standar 0.50. Pencarian validitas ini sama dengan uji validitas pada item (X1). maka variabel Kompensasi Non-Finansial (X2) dengan nilai AVE 0.51 dapat dikatakan memiliki nilai validitas yang baik dan lolos untuk uji validitas.

Hasil Uji validitas Variabel Kinerja Perusahaan (Y) sebagai variabel dpenden terhadap 64 responden dengan 30 item pertanyaan dengan rata-rata loading factor di atas standar 0.50. Pencarian validitas ini sama dengan uji validitas pada item variabel (X1) dan (X2). maka variabel Kinerja Perusahaan (Y) dengan nilai AVE 0.51 dapat dikatakan memiliki nilai validitas yang baik dan lolos untuk uji validitas. Pencarian validitas ini sama dengan uji yang dilakukan pada variabel (X1 dan X2).

\section{Uji Reliabilitas}

Composit Reliability

\begin{tabular}{|l|c|}
\hline & Original Sampel (O) \\
\hline Kinerja Perusahaan (Y) & 0.968 \\
\hline Kompensasi Finansial (X1) & 0.941 \\
\hline Kompensasi Non-Finansial (X2) & 0.938 \\
\hline
\end{tabular}

Cronbach Alpha

\begin{tabular}{|l|c|}
\hline & Original Sampel (O) \\
\hline Kinerja Perusahaan (Y) & 0.965 \\
\hline Kompensasi Finansial (X1) & 0.929 \\
\hline Kompensasi Non-Finansial (X2) & 0.929 \\
\hline
\end{tabular}

Berdasarkan tabel di atas, dapat disimpulkan bahwa nilai composit reliability setiap variabel X1, X2, dan Y memiliki nilai Composit Reliability diatas 0.50 sehingga ke-3 variabel dapat dinyatan lolos uji reliabilitas dengan nilai composit reliability dari masing-masing variabel X1 (0.968), X2 (0.941), dan Y (0.938) dan nilai Cronbach Alpha setiap variabel $\mathrm{X} 1, \mathrm{X} 2$ dan $\mathrm{Y}$ memiliki nilai Cronbach Alpha di atas 0.50 
sehingga ke-3 variabel dapat dinyatan lolos uji reliabilitas dengan nilai Cronbach Alpha dari masing-masing variabel X1 (0.965), X2 (0.929), dan Y (0.929)

\section{Uji hipotesis dan Pembahasan}

\begin{tabular}{|r|c|c|}
\hline & $\begin{array}{c}\text { Original } \\
\text { Sampel (O) }\end{array}$ & $\begin{array}{c}\text { T-Statistics } \\
(|\mathrm{O} / \mathrm{STERR}|)\end{array}$ \\
\hline Kompensasi Finansial (X1) -> Kinerja Perusahaan (Y) & 0.646 & 8.217 \\
\hline Kompensasi Non-Finansial (X2)-> Kinerja Perusahaan (Y) & 0.559 & 6.522 \\
\hline
\end{tabular}

\section{Hubungan Variabel Kompensasi Finansial dan Variabel Kinerja Perusahaan}

Hasil uji hipotesis yang menyatakan bahwa variabel Kompensasi Finansial (X1) dengan 12 item pertanyaan yang lolos uji validitas dan reliabilitas berpengaruh terhadap variabel kinerja perusahaan (Y) pada PT. Berlian Jasa Terminal Indonesia Cabang Kupang, untuk meyakinkan hubungan atau tingkat kekuatan hubungan antar variabel, estimasinya dapat dilihat pada uji koefisien parameter path dan tingkat signifiklansinya pada Tabel.di atas yang memperlihatkan bahwa terdapat hubungan antara variabel kompensasi financial terhadap kinerja perusahaan dengan koefisien sebesar 0.646 atau memiliki pengaruh dengan nilai loading factor diatas standar minimal 0,50. hal ini menunjukan bahwa persentanse sumbangan pengaruh variabel kompensasi financial memiliki pengaruh lebih besar secara signifikan terhadap kinerja perusahaan.

Hal ini mendukung hasil penelitian sebelumnya yaitu penelitian yang telah dilakukan oleh Polnaya (2007) dan Rahayu (2007). Polnaya (2007) menyatakan bahwa kompensasi financial berpengaruh positif dansignifikan terhadap kinerja dosen Universitas Kristen Indonesia Maluku. Hal ini dapat dilihat dari hasil uji t di peroleh nilai t hitung sebesar 5,351, sedangkan nilai t tabel sebesar 1,997 $(5,351>1,997)$. Selain itu, nilai signifikansinya adalah sebesar 0,000 lebih kecil dari pada taraf signifikansi $(\alpha)$ $0,05(0,000<0,05)$.

\section{Hubungan Variabel Kompensasi Non-finansial dan Variabel Kinerja Perusahaan}

Hasil uji hipotesis yang menyatakan bahwa variabel Kompensasi Finansial (X2) dengan 12 item pertanyaan yang lolos uji validitas dan reliabilitas berpengaruh terhadap variabel kinerja perusahaan (Y) padaPT. Berlian Jasa Terminal Indonesia Cabang Kupang, untuk meyakinkan hubungan atau tingkat kekuatan hubungan antar variabel, 
estimasinya dapat dilihat pada uji koefisien parameter path dan tingkat signifiklansinya pada Tabel 3.1.di atas yang memperlihatkan bahwa terdapat hubungan antara variabel kompensasi financial terhadap kinerja perusahaan dengan koefisien sebesar 0.559 atau memiliki pengaruh dengan nilai loading factor diatas standar minimal 0,50. hal ini menunjukan bahwa persentanse sumbangan pengaruh variabel kompensasi nonfinansial memiliki pengaruh lebih besar secara signifikan terhadap kinerja perusahaan.

Hal ini mendukung hasil penelitian sebelumnya yaitu hasil penelitian yang telah dilakukan oleh Polnaya (2007) dan Rahayu (2007). Polnaya (2007) menyatakan bahwa kompensasi nonfinansial berpengaruh positif dan signifikan terhadap kinerja dosen Kristen Indonesia Maluku. Hal ini dapat dilihat dari hasil ujit diperoleh nilai t hitung sebesar 3,474, sedangkan nilai t tabel sebesar 1,997 (3,474>1,997). Selain itu, nilai signifikansinya adalah sebesar 0,001 lebih kecil dari pada taraf signifikansi $(\alpha)$ 0,05 $(0,001<0,05)$.

\section{Kesimpulan}

Penelitian ini bertujuan untuk mengetahui pengaruh kompensasi finansial dan non-finansial terhadap kinerja perusahaan pada setiap karyawan yang bekerja pada PT.Berlian Jasa Terminal Indonesia Cabang Kupang. Berdasarkan analisis data dan pembahasan yang telah dilakukan,maka dapat ditarik kesimpulan sebagai berikut:

1) Kompensasi financial berpengaruh positif dan signifikan terhadap kinerja karyawan. Hal ini dapat dilihat dari nilai $\mathrm{t}$ hitung lebih besar dari $\mathrm{t}$ table (8.217>1.961) dan nilai signifikansi atau nilai standar lebih kecil dari taraf signifikansi $(\alpha) 1.961(1.961<8.217)$. Gozali 2006).

2) Kompensasi non-finansial berpengaruh positif dan signifikan terhadap kinerja karyawan. Hal ini dapat dilihat dari nilai $t$ hitung $>\mathrm{t}$ table $(6.552>1.961)$ dan signifikansi atau nilai standar lebih kecil dari taraf signifikansi $(\alpha) 1.961$ (1.961<6.552). (Gozali 2006)

\section{Saran}

Saran dari penelitian adalah sebagai berikut:

1) PT. Berlian Jasa Terminal Indonesia Cabang Kupang sebaiknya mempertahankan 
dan meningkatkan kompensasi finansial dan nonfinansialnya, karena kedua variabel ini dapat meningkatkan kinerja karyawannya sehingga dapat juga mempengaruhi kinerja perusahaan secara langsung.

2) Penelitian selanjutnya hendaknya memperluas sampel penelitian, tidak hanya padakaryawan PT. Berlian Jasa Terminal Indonesia Cabang Kupang, tetapi dapat mengambil sampel dari perusahaan perbankan, dagang, dan manufaktur. Atau dapat juga menambahkan variabel lain seperti gaya kepemimpinan, transparansi perusahaan, atau variabel-variabel laten lainnya, sehingga hasil penelitiannya dapat lebih tergeneralisasi.

\section{Daftar Pustaka}

Hasibuan, Malayu S.P. 2002. Manajemen Sumber Daya Manusia Edisi Revisi. i Aksara.

Mulyadi.(2012), Pengaruh Pemberian Kompensasi Terhadap Kinerja Karyawan pada PT. Balai Pustaka. Jurnal Economicus Vol5 Nol Maret 2012.

Panggabean, Mutiara S. 2002. Manajemen Sumber Daya Manusia. Jakarta: Ghallia Indonesia.

Sastrohadiwiryo, Bejo Siswanto. 2003. Manajemen Tenaga Kerja Indonesia Pendekatan Administrative dan Operasional. Jakarta: Bumi Aksara.

Simamora, Henry. 2004. Manajemen Sumber Daya Manusia. Yogyakarta: STIE-YKPN 